\title{
The hyperbenthic plankton community: composition, distribution, and abundance in a coral reef lagoon
}

\author{
J. H. Carleton ${ }^{1, *}$, W. M. Hamner ${ }^{2}$ \\ ${ }^{1}$ Australian Institute of Marine Science, PMB No. 3, Townsville Mail Centre, Queensland 4810, Australia \\ ${ }^{2}$ Department Ecology and Evolutionary Biology, University of California Los Angeles, Los Angeles, California 90290, USA
}

\begin{abstract}
Seasonal and diel variations in community structure and abundance of the lagoon hyperbenthic community were examined at Davies Reef, Great Barrier Reef. The lagoon floor community differed from that in the overlying water, it was faunistically more uniform, and it was assembled into statistically distinct seasonal and diel groupings. The lagoon floor community was characterized by reef-associated mysids, gammarids, calanoids, ostracods, harpacticoids, cyclopoids, nematodes, caprellids, and cumaceans. The community was most distinctive in October. The water column community had greater diel than seasonal variability. The nocturnal water column community was characterized by decapod larvae, zoea, larvaceans, fish larvae, gastropod larvae, and nauplii, but was dominated numerically by calanoid copepods $(>60 \%)$. Catches on the lagoon floor ranged from 750 to 3330 ind. $\mathrm{m}^{-3}$, with peak abundance in October, while water column catches were lower $\left(25\right.$ to 2500 ind. $\mathrm{m}^{-3}$ ), with peak nocturnal abundance in February. Most species in the hyperbenthic community do not migrate into the water column at night, but instead remain concentrated near the lagoon floor. Only the mysid Anisomysis laticauda, the copepod Acartia australis, and the ostracod Cypridina sp. A were consistently captured on the lagoon floor by day and in surface waters at night. The lagoon hyperbenthic community probably contributes to coral reef ecosystems through the remineralization of organic detritus. Given the high abundance of relatively large individuals, the contribution of the resident, lagoon floor community to coral reef ecosystems must be substantial.
\end{abstract}

KEY WORDS: Hyperbenthos · Plankton · Coral reef lagoon · Community structure

\section{INTRODUCTION}

Coral reef lagoons harbor an abundant, diverse community of resident plankton, which differs both qualitatively (Tranter \& George 1972, Gerber \& Marshall 1974, Renon 1977) and quantitatively (Motoda 1940, Johnson 1949, Tranter \& George 1972) from those in the surrounding sea. Unique resident assemblages are found throughout the water column (Johnson 1949, Tranter \& George 1972, Renon 1977, McKinnon 1991), residing near the lagoon floor (Hamner \& Carleton 1979, Carleton \& Hamner 1989), adjacent to coral outcrops (Emery 1968, McKinnon 1991), and within the reef substrate itself (see Jacoby \& Greenwood 1988 for review). However, the benthic boundary layer be- tween the water column and lagoon floor and the rich hyperbenthic community that occupies this zone remain, as in other marine ecosystems (Mees \& Jones 1997), relatively poorly studied. The hyperbenthos, defined as the assemblage of small, highly mobile animals living close to the sea floor comprised of endemic species, planktonic species at the deepest extension of their depth range, and endo- or epibenthic species as they emerge into the water column (Mees \& Jones 1997), can not be sampled well by conventional benthic or pelagic devices and is under-represented in core and grab samples. This is especially true for reef lagoons, where the presence of coral outcrops makes conventional sampling gear especially ineffective (Carleton \& Hamner 1987). 
Coral reef lagoons are zones of net heterotrophy requiring input of detritus from adjacent areas of high primary production (Wilkinson 1987, Alongi 1988). Initial attempts to model detritus-based food webs within the relatively enclosed lagoon at Davies Reef accounted for only $20 \%$ of incoming detrital material (MECOR - microbial ecology of a coral reef; Wilkinson 1987). These early studies concentrated on processes within the water column and within the sediments, and did not consider the role of the rich diversity of animals that blanket the lagoon floor. Subsequent studies determined that macro-infauna account for 3 to $11 \%$ of total organic matter (Riddle et al. 1990) and that sediment bacteria seasonally consume from 54 to $100 \%$ of the available carbon (Hansen et al. 1992), further enhancing our understanding of benthic processes, but still ignoring the trophodynamic role of the hyperbenthos.

Carleton \& Hamner (1987) developed a benthic sampler for use in coral reef lagoons to effectively study seasonal and diel variation in mysids (Carleton \& Hamner 1989), an integral component of the hyperbenthos in many littoral and coastal habitats (Mauchline 1980). Here, we present for the first time quantitative data on the composition, abundance, and variability of the entire hyperbenthic community that covers the floor of a coral reef lagoon, and we discuss the possible role of this community in coral reef ecosystems.

\section{MATERIALS AND METHODS}

Sampling. Two replicate diurnal and nocturnal plankton samples were collected at depths between 8 and $11 \mathrm{~m}$ from the lagoon floor at Davies Reef, Great Barrier Reef (Fig. 1), with a sampling device designed specifically to capture motile animals within a $10 \mathrm{~m}^{2}$ area up to $1 \mathrm{~m}$ above the sediment (Carleton \& Hamner 1987). Concurrent with the benthic sampling, 2 replicate samples were collected from the surface, mid-, and bottom layers of the water column with horizontally towed $0.5 \mathrm{~m}$ diameter, $235 \mu \mathrm{m}$ mesh plankton nets, and from the entire water column with $0.45 \mathrm{~m}$, $205 \mu \mathrm{m}$ nets towed vertically from the lagoon floor to the surface. Collections were made in July and October 1980 and in February and May 1981 ( $\mathrm{n}=120)$. In addition, 3 diurnal replicate samples were collected with the benthic sampler (September and December 1980 and March 1981; $\mathrm{n}=9$ ), with a $1.14 \times 0.32 \mathrm{~m}$ rectangular mouthed, $300 \mu \mathrm{m}$ mesh plankton sled (October 1980 and February 1981; $\mathrm{n}=6$ ), and with a diverswum 0.5 m, $235 \mu \mathrm{m}$ net (February 1981; $\mathrm{n}=3$ ). All nets were metered. Samples were fixed with $10 \%$ formaldehyde/filtered seawater. In the laboratory animals were separated from any sand that may have

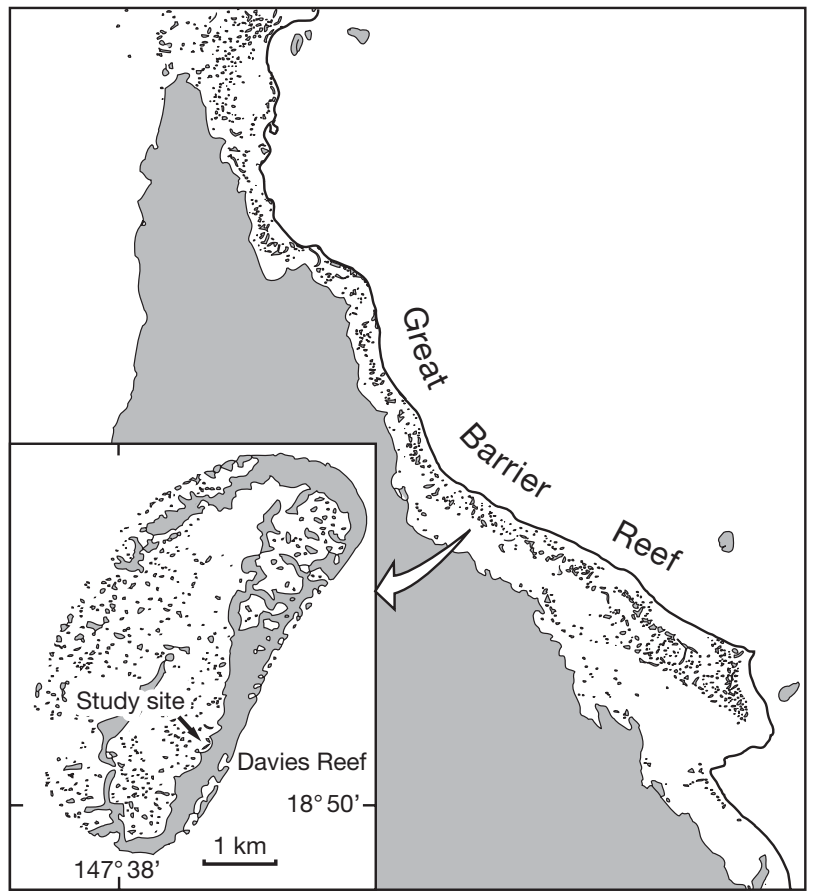

Fig. 1. Location of study site within Davies Reef lagoon, Great Barrier Reef

been present by repeatedly swirling the samples and decanting the supernatant through a series of sieves until the wash was free of plankton (Birkett \& McIntyre 1971). Large or rare organisms were removed and counted. Subsamples ranging from $1 / 4$ to $1 / 32$ of the total catch were examined for composition and abundance under a stereoscopic microscope. Counts from both benthic and net samples were standardized to ind. $\mathrm{m}^{-3}$ prior to statistical analyses.

Data analysis. Associations among 60 broad taxonomic categories were investigated by agglomerative, hierarchical clustering techniques. Bray-Curtis dissimilarity coefficients (Bray \& Curtis 1957) were calculated for every possible pair of samples $(\mathrm{n}=92)$, and the resulting association matrix was subjected to an unweighted pair-group average (UPGMA) clustering procedure ( $\beta=0.0$; Belbin 1987). The hierarchy and groupings were validated by the methods of Sandland \& Young $(1979 a, b)$. Classification groups were verified with independent ordination procedures (Field et al. 1982) by subjecting the association matrix to a principal co-ordinate analysis (PCO). The results were illustrated in a 2-dimensional biplot that combined output from the cluster analysis, in terms of labeling samples by cluster membership, with the eigenvectors for the various broad taxonomic categories. Data were 4th-root transformed to ameliorate the effects of disparate abundance estimates. Taxon richness, abundance, and evenness index $\left(J^{\prime}\right.$; Pielou 1969, 1975) were 
Table 1. Mean abundance for lagoon floor species/taxa

\begin{tabular}{|c|c|c|}
\hline Taxa & Species & $\begin{array}{l}\text { Abundance } \\
\text { (ind. } \mathrm{m}^{-3} \text { ) }\end{array}$ \\
\hline Mysidacea & $\begin{array}{l}\text { Erythrops nana } \\
\text { Anisomysis pelewensis } \\
\text { Doxomysis littoralis } \\
\text { Anisomysis laticauda } \\
\text { Prionomysis stenolepis } \\
\text { Pseudanchialina inermis } \\
\text { Anisomysis lamellicauda } \\
\text { Anisomysis australis } \\
\text { Anchialina grossa } \\
\text { Hemisiriella parva } \\
\text { Gastrosaccus indicus } \\
\text { Hemisiriella pulchra } \\
\text { Siriella aequiremis } \\
\text { Siriella gracilis } \\
\text { Siriella sp. A } \\
\text { Siriella nodosa } \\
\text { Anisomysis bifurcata }\end{array}$ & $\begin{array}{c}197.7 \\
124.7 \\
38.82 \\
13.36 \\
9.2 \\
5.65 \\
2.31 \\
1.67 \\
0.62 \\
0.56 \\
0.36 \\
0.28 \\
0.08 \\
0.05 \\
0.04 \\
0.02 \\
0.01 \\
0.005\end{array}$ \\
\hline Gammaridea & $\begin{array}{l}\text { Moolapheonoides sp. } \\
\text { Oediceroides ?apicalis } \\
\text { Dexaminidae sp. A } \\
\text { Bemlos australis } \\
\text { Ampithoe spp. } \\
\text { Leucothoe sp. A } \\
\text { Dexaminidae sp. B } \\
\text { Phoxocephalidae } \\
\text { Ampelisca ?acinaces } \\
\text { Urothoe sp. } \\
\text { Aorchoides sp. } \\
\text { Synopia ?ultramarina } \\
\text { Leucothoe sp. B } \\
\text { Aoridae } \\
\text { Oediceroides sp. } \\
\text { Eusiridae } \\
\text { Synopia sp. } \\
\text { Other gammarids }\end{array}$ & $\begin{array}{c}259.6 \\
132.49 \\
92.42 \\
22.12 \\
2.30 \\
2.08 \\
1.75 \\
1.60 \\
1.49 \\
0.88 \\
0.74 \\
0.70 \\
0.45 \\
0.20 \\
0.10 \\
0.09 \\
0.07 \\
0.005 \\
0.12\end{array}$ \\
\hline Calanoida & $\begin{array}{l}\text { Acartia australis } \\
\text { Other calanoids }\end{array}$ & $\begin{array}{r}412.6 \\
45.95 \\
366.61\end{array}$ \\
\hline Ostracoda & $\begin{array}{l}\text { Pterocypridina sp. A } \\
\text { Cypris spp. } \\
\text { Cypridinodes sp. A } \\
\text { Vargula sp. A } \\
\text { Cylindroleberis sp. A } \\
\text { Tetraleberis brevis } \\
\text { Siphonostra sp. A } \\
\text { Eusarsiella sp. A } \\
\text { Cypridina sp. A } \\
\text { Eusarsiella springthorpei } \\
\text { Eusarsiella claviformis } \\
\text { Parasterope sp. A } \\
\text { Euphilomedes sp. A } \\
\text { Pterocypridina sp. B } \\
\text { Other ostracods }\end{array}$ & $\begin{array}{r}115.8 \\
17.77 \\
56.30 \\
4.70 \\
6.98 \\
6.43 \\
3.60 \\
2.64 \\
2.50 \\
3.41 \\
1.60 \\
1.69 \\
3.86 \\
1.02 \\
2.68 \\
0.60\end{array}$ \\
\hline Cumacea & & 20.3 \\
\hline Harpacticoida & $\begin{array}{l}\text { Metis sp. } \\
\text { Other harpacticoids }\end{array}$ & $\begin{array}{c}211.5 \\
27.96 \\
183.5\end{array}$ \\
\hline Cyclopoida & & 140.5 \\
\hline Nematoda & & 45.1 \\
\hline Caprellidae & & 38.3 \\
\hline
\end{tabular}

determined for each sample grouping. Further analyses and diagnostics focused on those taxa identified by the PCO as belonging to the lagoon floor community.

For seasonal and day/night changes in the lagoon floor community (composition and abundance), only samples from the benthic sampler were subjected to an unbalanced, 2-way, fixed factor, non-parametric multivariate analysis of variance (NPMANOVA). The first factor contained 7 levels (July, September, October, December, February, March, and May) and the second factor contained 2 levels (diurnal and nocturnal data for July, October, February, and May). There were 2 replicate samples per cell producing a data matrix containing 58 species/taxa columns (Table 1) and 22 sample rows. Primary factors and interactions were tested individually by DISTLM (Anderson 2000), a program that performs a non-parametric test for the multivariate null hypothesis of no relationship between a data matrix and a design matrix that codes for a particular term in the model. This is achieved through multivariate regression analysis on a matrix of distance measures (McArdle \& Anderson 2001). The design matrices to test the various null hypotheses were created with XMATRIX (Anderson 2003). Data were again 4throot transformed, and the Bray-Curtis dissimilarity coefficient was used as the distance measure. The species/taxa that contributed most to seasonal and diurnal differences in the lagoon floor community structure were determined by a diagnostic routine that examined the contribution of each species/taxon to the average Bray-Curtis dissimilarity measure between all possible pairs of sample groupings within each factor (Clarke 1993). There were 21 pair combinations for the first factor of month and only 1 pair for the day/night factor.

Differences in catches among the benthic sampler, plankton sled, diver-swum net, and deep boat-towed net were compared for 10 prevalent lagoon floor taxa with 1-way, fixed-factor analysis of variance (ANOVA). Prior to analysis, data were 4th-root transformed and tested for heteroscedasticity by Cochran's procedure (Winer 1971). For those taxa that differed significantly, homogeneous subsets were extracted by Tukey's HSD-test (Zar 1984). The critical probability level for significance testing was set a priori at $5 \%$ for all statistical procedures.

\section{RESULTS}

\section{Distribution and abundance}

Classification of all 92 samples based on 60 broad taxonomic categories produced 11 statistically significant groups (Grs) (Sandland \& Young 1979a,b). The 
first split, at a high level of dissimilarity, separated all benthic (Grs 1 to 4) from all net (Grs 5 to 11) samples (Table 2). The benthic samples disassociated further at quite low levels of dissimilarity into 4 distinct groups: all samples from October (Gr 1); diurnal samples from February, March, and May (Gr 2); diurnal samples from September and December (Gr 3); and all samples from July and nocturnal samples from February and May (Gr 4). The net samples split into 2 broad groupings based primarily on differences between day and night. The group containing only diurnal samples split into a group containing samples from vertically towed nets (Gr 5) and a group containing all surface and the majority of mid-depth samples (63\%) from horizontally towed nets ( $\mathrm{Gr} 6$ ). The remaining broad grouping contained 5 distinct groups: all nocturnal plankton tows, both horizontal and vertical, from February (Gr 7); all nocturnal plankton tows from May (Gr 8); all nocturnal horizontal net samples from October and those from the mid-depth strata in July plus a single nocturnal vertical tow sample from each of October and July (Gr 9); a group containing a disproportionate representation of diurnal samples from the deep strata (Gr 10); and all samples from the plankton sled and diverswum net (Gr 11).

The results of the $\mathrm{PCO}$ were consistent with those from the cluster analysis (Fig. 2). The greatest proportion of variation in the data set was explained by the first dimension $(\sim 40 \%)$ and represented differences between benthic (Grs 1 to 4) and net (Grs 5 to 11) samples. The second dimension explained approximately $15 \%$ of the variance and was indicative of day/night differences in net samples. Nocturnal net samples (Grs 7 to 9) were closely associated in 2-dimensional space, whereas diurnal net groups (Grs 5, 6, and 10) were more diffuse (higher level of dissimilarity). A high degree of similarity among benthic groups is indicated by the overlap in the $95 \%$ confidence ellipses for the individual group means. The PCO identified 16 important taxonomic categories from the 60 analyzed (Fig. 2). The vectors for gammarids, harpacticoids, caprellids, nematodes, and cumaceans were associated with samples from the benthic sampler (Grs 1 to 4 ). The vectors for decapod larvae, zoea, larvaceans, fish larvae, gastropod larvae, fish eggs, and nauplii were associated with nocturnal plankton net samples from October, May, and February (Grs 7 to 9). Calanoid and cyclopoid copepods, mysids and ostracods were associated with samples from both the water column and lagoon floor. Groups containing diurnal plankton net samples (Grs 5 and 6) were not affiliated with any taxa.

\section{Water column community}

The water column community (Grs 5 to 10, Fig. 2) had much greater diel than seasonal variation, was most abundant in February (Gr 7, Fig. 3) and was dominated numerically by copepods ( 60 to $90 \%)$. Day catches (Grs 5, 6 and 10; Fig. 3) were small (25 to $\left.414 \mathrm{~m}^{-3}\right)$, contained few taxa (11 to 20) and varied in relative abundances $\left(J^{\prime}=0.65\right.$ and 0.31$)$. Diurnal calanoid assemblages contained both pelagic and reef associated species but Acartia australis was most

Table 2. Sample composition of the 11 significant groups ( $p>0.05$, Sandland \& Young 1979a,b) from the classification analysis on 92 samples collected during the study for 60 broad taxonomic categories (Bray-Curtis dissimilarity measure, UPGMA fusion strategy). First letter in sample code is gear type (D: diver-swum plankton net; N: horizontally towed net; S: plankton sled; T: benthic sampler; V: vertically towed net); second letter represents time of day (D: day; N: night); next 3 represent month; next represents depth strata (S: surface; M: mid; D: deep; B: bottom), and the final number is the replicate

\begin{tabular}{|c|c|c|c|c|c|c|c|c|c|c|}
\hline Gr 1 & Gr 2 & Gr 3 & Gr 4 & Gr 5 & Gr 6 & Gr 7 & Gr 8 & Gr 9 & Gr 10 & Gr 11 \\
\hline TDOctB1 & TDFebB1 & TDDecB1 & TDJulB1 & VDFebC1 & NDFebM2 & NNFebD1 & NNMayD1 & NNJulM1 & NDFebD1 & DDFebB1 \\
\hline TDOctB2 & TDFebB2 & TDDecB2 & TDJulB2 & VDFebC2 & NDFebS1 & NNFebD2 & NNMayD2 & NNJulM2 & NDFebD2 & DDFebB2 \\
\hline TNOctB1 & TDMarB1 & TDSepB1 & TNFebB1 & VDJulC1 & NDFebS2 & NNFebM1 & NNMayM1 & NNJulS2 & NDFebM1 & SDFebB1 \\
\hline \multirow[t]{14}{*}{ TNOctB2 } & TDMarB2 & TDSepB2 & TNFebB2 & VDJulC2 & NDJulD2 & NNFebM2 & NNMayM2 & NNOctD1 & NDJulD1 & SDFebB2 \\
\hline & TDMayB1 & & TNJulB1 & VDMayC1 & NDJulM1 & NNFebS1 & NNMayS1 & NNOctD2 & NDMayM1 & SDOctB1 \\
\hline & TDMayB2 & & TNJulB2 & VDMayC2 & NDJulM2 & NNFebS2 & NNMayS2 & NNOctM1 & NDOctD1 & SDOctB2 \\
\hline & & & TNMayB1 & & NDJulS1 & VNFebC1 & VNMayC1 & NNOctM2 & NDOctD2 & \\
\hline & & & TNMayB2 & & NDJulS2 & VNFebC2 & VNMayC2 & NNOctS1 & NDOctM2 & \\
\hline & & & & & NDMayD1 & & & NNOctS2 & NNJulD2 & \\
\hline & & & & & NDMayD2 & & & VNJulC2 & NNJulS1 & \\
\hline & & & & & NDMayM2 & & & VNOctC2 & VDOctC1 & \\
\hline & & & & & NDMayS1 & & & & VDOctC2 & \\
\hline & & & & & NDMayS2 & & & & VNJulC1 & \\
\hline & & & & & NDOctM1 & & & & VNOctC1 & \\
\hline & & & & & NDOctS1 & & & & & \\
\hline & & & & & NDOctS2 & & & & & \\
\hline & & & & & NNJulD1 & & & & & \\
\hline
\end{tabular}




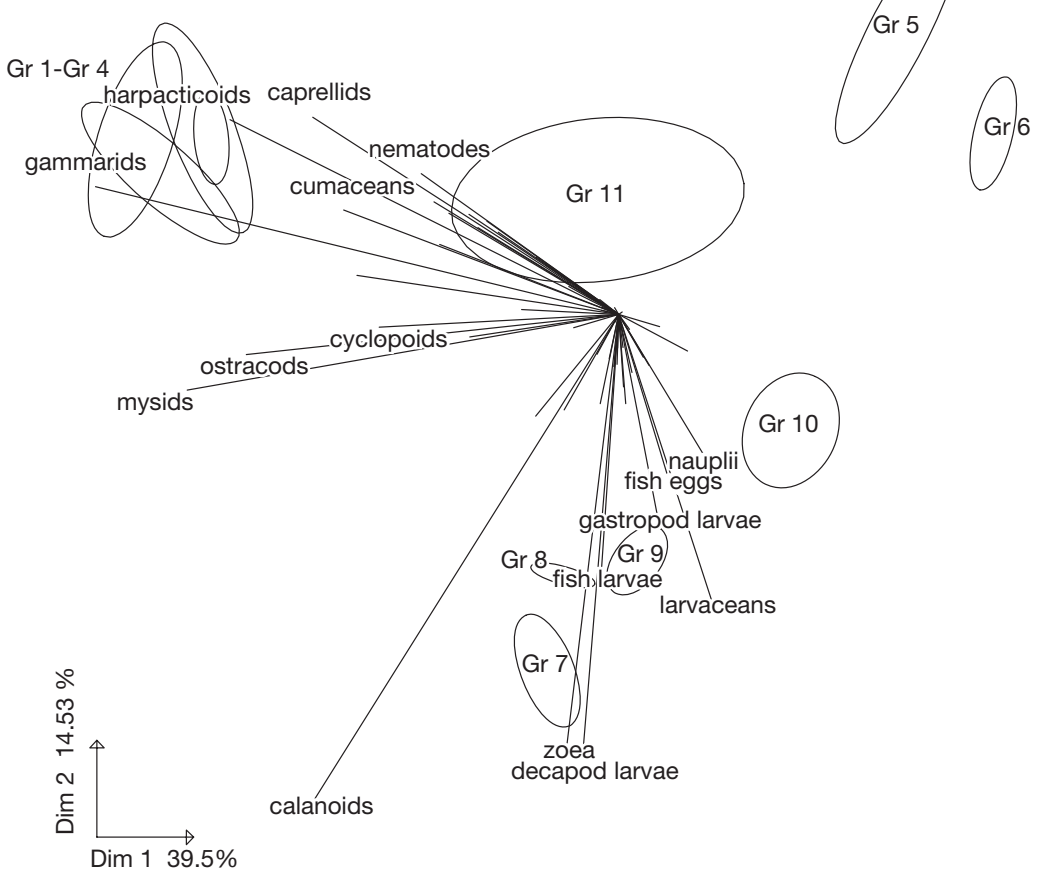

Fig. 2. Biplot summarizing results from principal co-ordinate analysis on matrix of Bray-Curtis measures employed in cluster analysis. Plot combines $95 \%$ confidence ellipses for means of sample groupings generated by classification analysis with eigenvectors of taxonomic categories

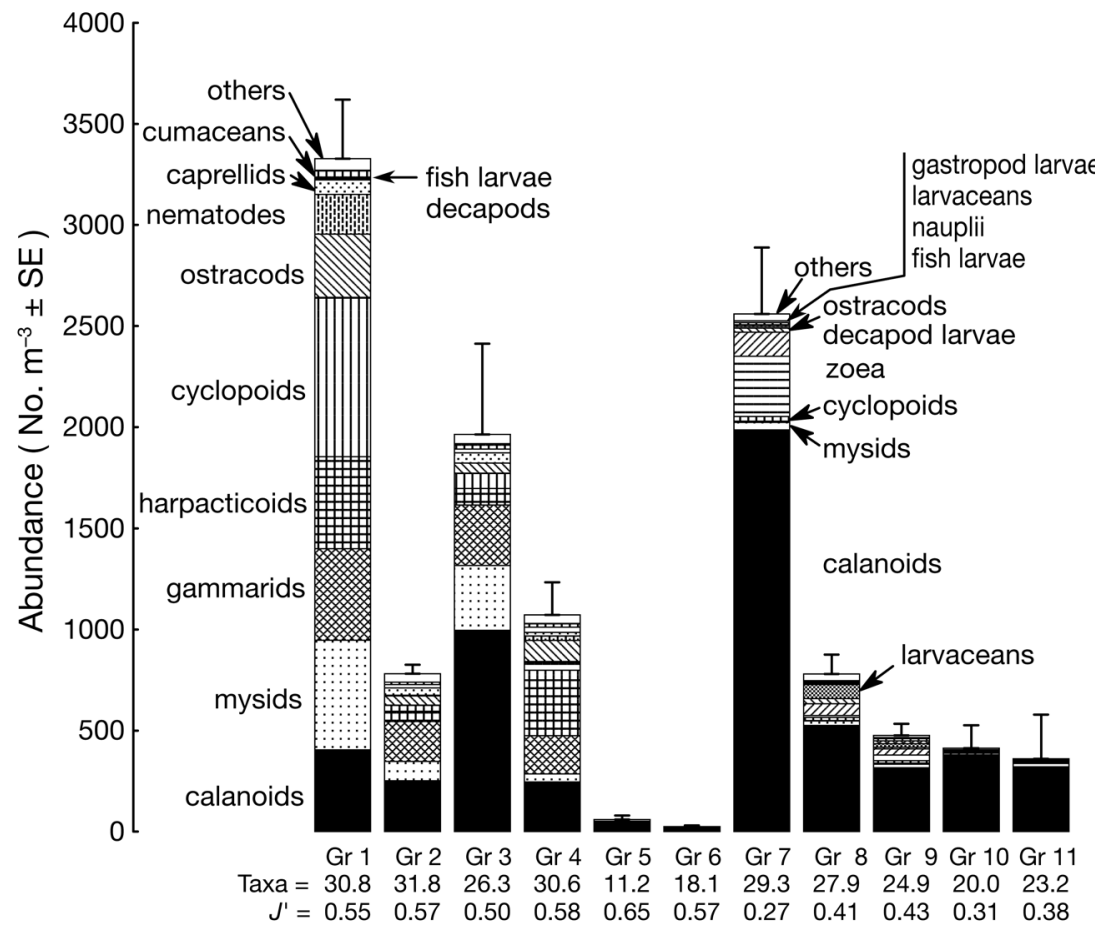

Fig. 3. Stacked bar chart of taxonomic composition and abundance for each sample grouping generated by the classification analysis. Number of taxa and Pielou's evenness index $\left(J^{\prime}\right)$ listed beneath code for each sample grouping abundant in the mid and deep strata, especially during October. The diurnal community also included both transient meroplanktonic forms (such as gastropod larvae, fish eggs and fish larvae) and holoplanktonic forms (such as larvaceans, cyclopoids, and harpacticoids). Nocturnal plankton populations in the water column ( $\mathrm{Gr} 7$ to 9) were larger (476 to $2560 \mathrm{~m}^{-3}$ ), contained more taxa (25 to 29 ) and were distinctive in composition and abundance during October, February and May (Fig. 2). The nocturnal community contained numerous reef associated species such as mysids (primarily Anisomysis laticauda) and ostracods (primarily Cypridina sp. A) but was dominated numerically by calanoids $(\sim 70 \%)$. Calanoid copepods were most abundant at night in February ( $\mathrm{Gr} 7, J^{\prime}=0.27$, Fig. 3). Large catches of zoea and decapod larvae were also taken at that time, as well as notable catches of mysids, cyclopoids and ostracods. Calanoids also dominated nocturnal net samples from May (Gr 8, $J^{\prime}=0.41$ ) and October/July (Gr 9, $\left.J^{\prime}=0.43\right)$.

\section{Hyperbenthic community}

The lagoon floor community (Grs 1 to 4) was fairly uniform in composition throughout the year and between day and night (Fig. 2) with calanoids, mysids, gammarids, harpacticoids, cyclopoids, ostracods, nematodes, caprellids and cumaceans well represented in all benthic sample groupings (Fig. 3). The greatest catches were in October (Gr 1), followed by diurnal catches from September and December (Gr 3), then all July catches and nocturnal catches from February and May (Gr 4), and finally diurnal catches from February, March and May (G2). Benthic groups (Grs 1 to 4) contained a large number of taxa $(31,32,26$ and 31, respectively) which were evenly proportioned in their abundance $\left(J^{\prime}=0.55,0.57,0.50\right.$ and 0.58). Gr 3 had fewer taxa and a disproportionately high abundance of calanoid copepods, the most abundant taxa in benthic samples (Table 1). 
In spite of fairly uniform species composition the lagoon floor community differed significantly throughout the year ( $<<0.001, F_{6,8}=3.0$, NPMANOVA) and between day and night $\left(\mathrm{p}<0.001, F_{1,8}=5.06\right.$, NPMANOVA), with no significant interaction. Sixty percent of the variation in benthic samples was explained by month, and $17 \%$, by time of day. The $a$ posteriori diagnostics among months found that the community structure in October was most distinctive to other times of the year. Seventeen species/taxa contributed substantially to the total average dissimilarity in at least $20 \%(>4)$ of the 21 pair-wise comparisons (Fig. 4). The majority of these animals had peak abundance during austral spring and early summer from September through to December and a minimum in March. However, there were notable exceptions: Anisomysis pelewensis and Doxomysis littoralis had secondary peaks in May, as did Metis sp.; Dexaminidae had a secondary peak in March, as did Acartia australis; ostracods were relatively abundant in July; and Pseudanchialina inermis was most abundant from February to May. The taxa that contributed most to the average dissimilarity between day and night fell into 3 broad distribution patterns. Anisomysis laticauda, A. lamellicauda, Acartia australis, and other calanoids were more abundant on the lagoon floor during the day and diffused into the water column at night; Erythrops nana and Oediceroides ?apicalis also were less abundant on the lagoon floor at night, but had no affinity with the water column; whereas cyclopoids, harpacticoids, nematodes, and Vargula sp. were more abundant on the lagoon floor at night.

\section{Sampler efficiency}

The benthic sampler captured 127 species/taxa ranging in escape response from small, virtually immobile benthic ctenophores to relatively large, highly mobile lagoon fish. However, most of the species/taxa were quite rare and ten of the twelve most abundant taxa were crustaceans, including many peracarids. In addition to 17 species of mysids (Table 1), the device captured 18 gammaridean taxa, 5 taxa of isopods (Cilicaeopsis whiteleggei, Accalathura oryza, Cirolana sp., Gnathia sp. and Bopyridae), 2 tanaidaceans (Leptochelia minuta and Apseudidae sp.), caprellids and cumaceans.

The benthic sampler captured significantly more ( $p<0.05$, Tukey's HSD-test) gammarids, caprellids, cumaceans, tanaids, ostracods, harpacticoids, and nematodes than the other sampling devices (Fig. 5). Significantly fewer isopods were taken with the boattowed net, and fewer calanoids, by the plankton sled. Cyclopoids had heteroscedastic variance.

\section{DISCUSSION}

\section{Zooplankton sampling efficiency}

The benthic sampler was designed explicitly to exploit the escape behavior of motile animals to enable their capture and has proved more successful than conventional sampling devices in capturing the many species of mysid that blanket the floor of Davies Reef lagoon (Carleton \& Hamner 1987). In the present study, multivariate analyses placed all samples from the diver-swum net and plankton sled in a group distinct from the benthic sampler, again suggesting differences in sampling efficiency.

These differences were confirmed by direct univariate comparisons on the more abundant species/taxa. The benthic sampler outperformed a diver-swum net, plankton sled, and boat-towed net in 7 out of 10 taxonomic categories and produced equivalent catches in the remaining 3 . These results are not surprising as most of the 10 more abundant taxa live on or very close to the sediment. The boat-towed net rose off the lagoon floor at the start of a tow and fished about $1 \mathrm{~m}$ above the bottom, while the plankton sled, a device traditionally used for sampling near the seafloor, had runners which held the net mouth $10 \mathrm{~cm}$ above the bottom. Only the diver-swum net could follow the contours of the lagoon floor dipping in and out of the declivities between the sand rills.

The benthic sampler underestimated the abundance of nematodes and calanoid copepods. Alongi (1986) sampled specifically for free-living nematodes in Davies Reef lagoon and he obtained densities ranging from 3 to 4 orders of magnitude greater than present catches. The benthic sampler was not designed to collect meiobenthic fauna within the sediments, and those nematodes recorded from benthic samples were most likely disturbed from the top few centimeters during sampling or associated with sediment swept into the device. Up to $75 \%$ of the benthic calanoid copepods were Acartia australis. Hamner \& Carleton (1979), using diver-swum and boat-towed nets, estimated the diurnal abundance of non-swarming A. australis in Davies Reef lagoon to range between approximately 20 and 4700 ind. $\mathrm{m}^{-3}$ during the spring and summer, with maximum abundances in November. The present density estimates for $A$. australis were generally much lower, and peak abundances occurred from December to March (Fig. 4). Continual disturbance of $A$. australis swarms causes many of the copepods to swim upwards (authors' pers. obs.). Since the top of the $10 \mathrm{~m}^{2}$ benthic enclosure was open, this behavior would result in the loss of catch and an underestimation of their true abundance. A. australis catches did, in fact, differ sig- 

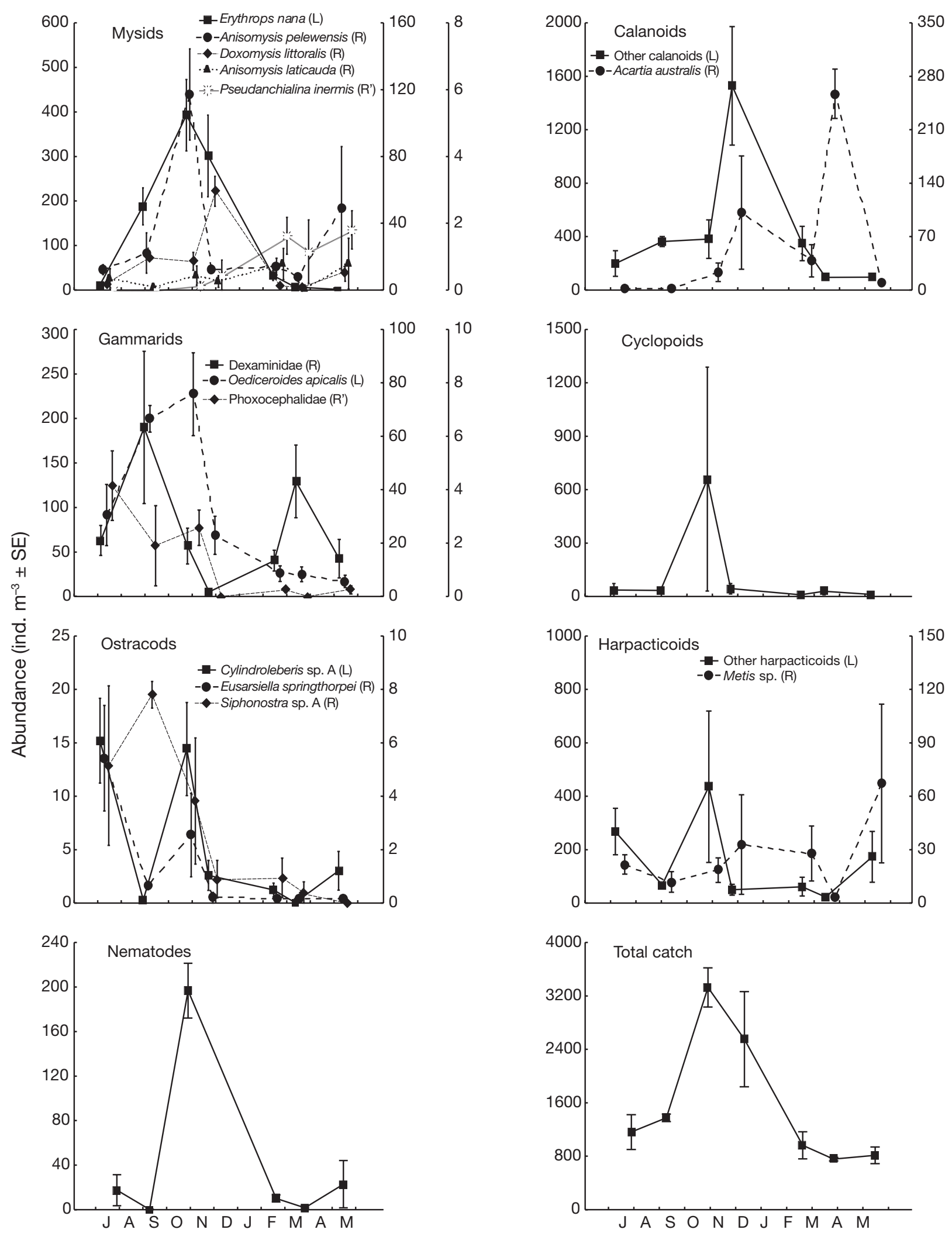

Fig. 4. Plots of mean abundance for total catch and those lagoon floor species/taxa identified by a posteriori diagnostic routines (Clarke 1993) as contributing most to total average dissimilarity (Bray-Curtis measures) among months (L: left axis; R: right axis; $\mathrm{R}^{\prime}$ : far right axis) 


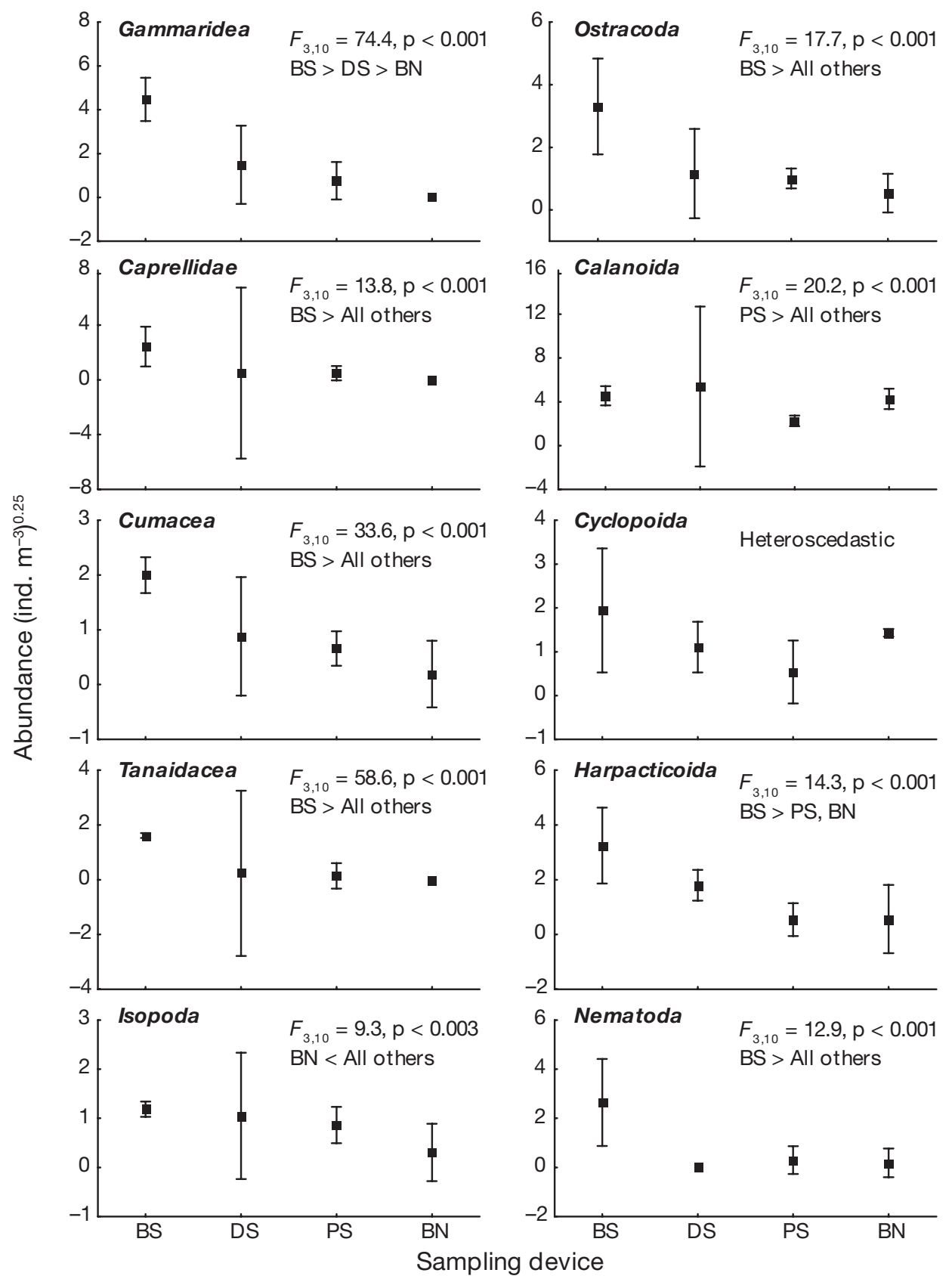

Fig. 5. Comparison of catches $( \pm 0.95 \mathrm{CI})$ from the benthic sampler (BS) with those from a diver-swum net (DS), a plankton sled (PS), and a boat-towed net (BN) for peracarids and the most abundant taxa from the lagoon floor community. ANOVA results and those from Tukey's HSD-test are inserted in each plot

nificantly between sampling devices $(p<0.05$, Kruskal-Wallis tests), with diver-swum nets capturing significantly more copepods $\left(470\right.$ ind. $\left.\mathrm{m}^{-3}\right)$ than the boat-towed net $\left(260\right.$ ind. $\left.\mathrm{m}^{-3}\right)$, which, in turn, captured more animals than either the benthic sampler (47 ind. $\mathrm{m}^{-3}$ ) or plankton sled $\left(20\right.$ ind. $\left.\mathrm{m}^{-3}\right)$.

With the exception of Acartia australis and lagoon fish (Gobioidei), which were observed to avoid capture by diving into holes in the lagoon floor, the majority of key taxa comprising the lagoon floor community appear to be adequately sampled by the benthic sampler. Furthermore, the device captures exceptionally important lagoon floor animals like mysids that are either poorly sampled or not sampled at all by more conventional means. Admittedly, the benthic sampler requires considerably more time and effort to deploy and to operate than conventional techniques, but catches were often an order of magnitude or 
more higher (Fig. 5), an important consideration when estimating standing stock, production, and consumption.

\section{Water column community}

Up to $75 \%$ of the copepods that dominated the water column community were Acartia australis. Hamner \& Carleton (1979) noted the same diel distribution pattern for this copepod as observed in the present study, with most copepods close to the bottom during the day and more uniformly distributed throughout the water column at night. In the spring and summer $A$. australis form dense swarms during the day near coral outcrops on the lagoon floor that are not easily sampled by conventional procedures (Hamner \& Carleton 1979, McKinnon 1991). Nevertheless, Hamner \& Carleton (1979), through a variety of sampling procedures, obtained maximum abundances in November when this species formed 'a solid blanket $2 \mathrm{~m}$ thick across the lagoon floor'. In the present study $A$. australis was prevalent in benthic and net catches from October to March, but it was difficult to determine peak abundance due to variable catch rates between sampling procedures. For example, diurnal benthic catches were greatest from December to March, whereas diurnal horizontal and vertical net catches were highest in October. Nocturnal benthic catches were greatest in October, but nocturnal net catches were highest in February. These conflicting patterns may not be due to sampler bias alone, but may also be due to the different phases of the moon. Decreased nocturnal light level is a major cue in stimulating emergence and subsequent vertical migration of demersal zooplankton (Alldredge \& King 1980, Jacoby \& Greenwood 1988) and could very well have a similar influence on $A$. australis. In February, sampling was conducted during the first quarter, but in October the moon was full. Reduced moonlight in February may also explain the high diversity and abundance of other species in the water column at that time (Fig. 3).

McKinnon (1991), using vertically towed nets with much finer mesh $(64 \mu \mathrm{m})$, found that Acartia australis was most abundant in December, but, throughout the rest of the year, the copepod community in Davies Reef lagoon was actually dominated by very small copepods (Oithona and Parvocalanus), an important new finding associated with the use of finer meshed nets. Roman et al. (1990) also used $64 \mu \mathrm{m}$ mesh nets, and they obtained results similar to those of McKinnon (1991) in that the diurnal water column was dominated by very small pelagic copepods. However, they also noted that maximum densities occurred at high-tide periods and minimum densities at mid-day low tide. In the present study, with the exception of a low tide in May, all net samples were collected during ebb tide. May nocturnal net samples were large and diverse despite a low tide (Fig. 3), and the diurnal samples clustered with all other diurnal samples regardless of tidal phase. Gear type (horizontal or vertical net tows) had a more significant impact (Fig. 3). Roman et al. (1990) also monitored diel water column zooplankton in the back-reef lagoon and, as in the present study, found that the abundance of all zooplankton taxa increased at night, with reef-associated forms such as mysids, prawns, and crab larvae having the greatest diel differences and calanoid copepods the least.

\section{Lagoon floor community}

Composition of the Davies Reef lagoon floor community did not change markedly throughout the year (Fig. 2), results similar to those found previously for resident and demersal communities in other coral reef lagoons (Sale et al. 1978, McWilliams et al. 1981). At Davies Reef the same 9 taxa were always present (Fig. 3) and dissimilarities in community structure resulted primarily from changes in the relative abundance of a number of key species/taxa (Fig. 4). In contrast to the water column community, diel differences were smaller than seasonal differences (Fig. 2), with only $17 \%$ of total variance explained by time of sampling. This seasonal and diel uniformity in community structure is quite probably due to the fact that most of the hyperbenthic community does not migrate into the surface waters at night, but remains concentrated on or near the substratum and was not, therefore, flushed from the lagoon by tidal or wind-driven surface currents. Only Anisomysis laticauda, Acartia australis, and Cyridina sp. A were consistently captured on the lagoon floor by day and in surface waters at night. The greatest nocturnal water column concentrations of these species occurred in February and May, when other more transient members of the lagoon floor community (Pseudanchialina inermis, Pterocypridina sp. A, and Synopia ?ultramarina) were also present at the surface. As noted above, reduced moonlight levels in February and May might explain these high nocturnal water column abundances.

Although the benthic sampler and emergence traps target different communities and rely on different aspects of behaviour to capture animals, there is some overlap in catch composition. All 17 emergent taxa considered by Alldredge \& King (1977) at Lizard Island on the Great Barrier Reef were also represented in our samples, and 7 of the 10 crustacean taxa in their samples were important in defining the lagoon floor 
community at Davies Reef (Table 3). The benthic sampler captured more mysids, gammarids, harpacticoids, and nematodes than emergence traps placed in lagoon and sand flat habitats, and similar numbers of ostracods, calanoids, and cumaceans, but fewer cyclopoids and isopods. However, benthic catches of cyclopoids in October, when lagoon floor organisms were most abundant in Davies Reef lagoon, were greater than the Lizard Island summer catches. McWilliams et al. (1981) working at One Tree Reef on the Great Barrier Reef considered only 7 general categories of taxa and did not present data on individual orders of peracarids. They did, however, list the 6 families of gammarids captured in their emergence traps; 5 of these families, namely, Oedicerotidae, Synopiidae, Dexaminidae, Ampeliscidae, and Phoxocephalidae, were also found in Davies Reef lagoon. Winter catches in the present study were greater for peracarids and ostracods than emergence trap catches from One Tree Reef and were comparable for calanoids, cyclopoids, and harpacticoids. Summer catches were comparable for peracarids, ostracods, and calanoids and were greater in the emergence traps for cyclopoids and harpacticoids. Again, October catches of cyclopoids from Davies Reef were higher than the One Tree Reef summer catches and similar for harpacticoids.

It has been suggested that the hyperbenthos plays an important role in the coupling of benthic and pelagic food webs through daily vertical migrations. As noted earlier, the majority of lagoon floor taxa, unlike other resident demersal plankton (see Jacoby \& Greenwood 1988 for review) or hyperbenthic species in other ecosystems (Mees \& Jones 1997), do not undertake extensive nocturnal migrations into the water column and only Anisomysis laticauda, Acartia australis, and Cyridina sp. may play an important part in the tight benthic-pelagic coupling prevalent on coral reefs (Alongi 1998). The majority of species/taxa responsible for seasonal variation in the lagoon floor community

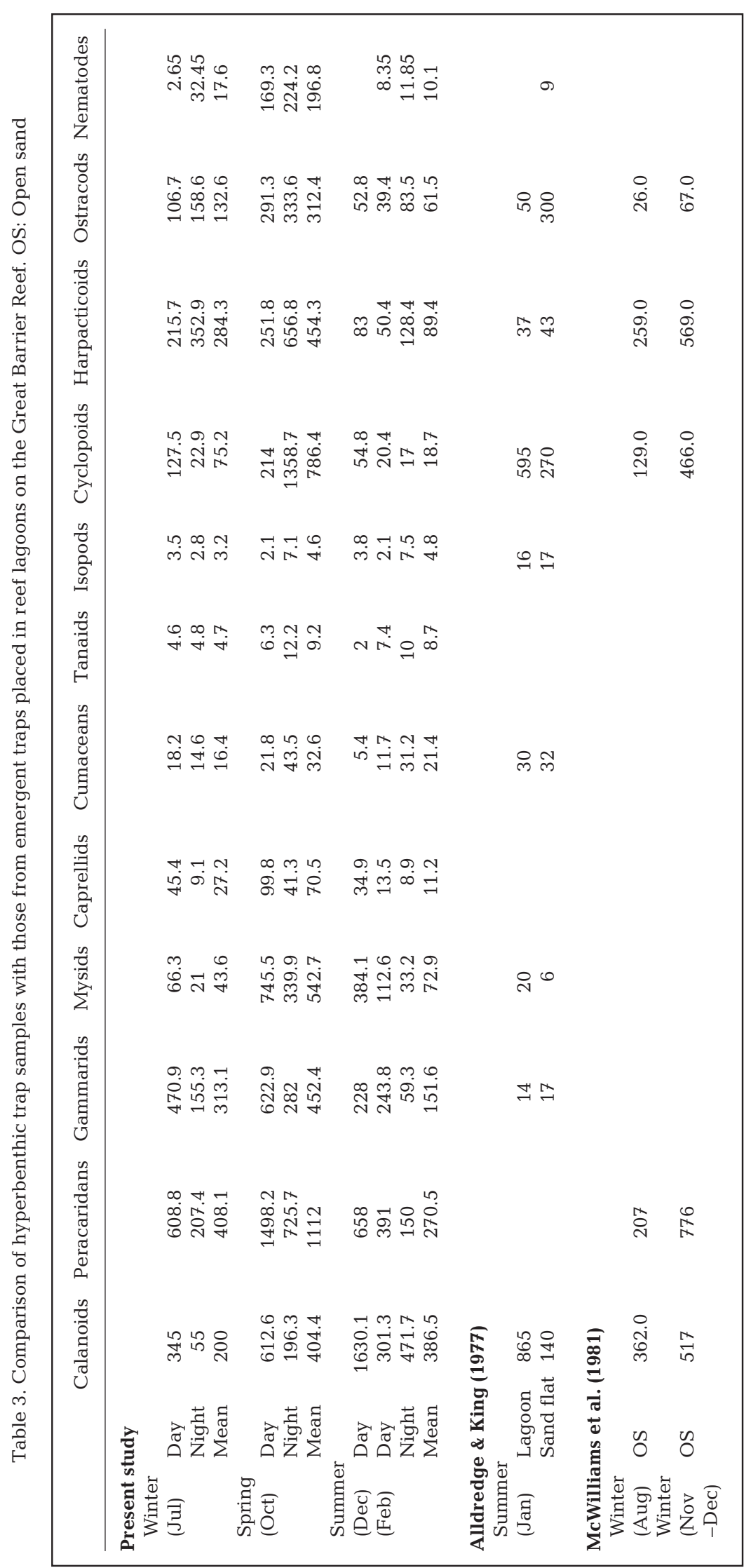


were most abundant during austral spring and early summer from September to December (Fig. 4). These high densities coincide with the October maximum in lagoon deposition rates of detritus rather than the February/May peak in primary production (Hansen et al. 1992). Consistent with many coastal and littoral species (Mauchline 1980), mysids in Davies Reef lagoon function as detitivores, remineralizing a substantial portion of lagoon organic detritus ( 20\% in spring; Carleton \& McKinnon, this issue). Gammarids and ostracods are also detritus feeders and scavengers, although ostracods are known to display diverse feeding habits. Ostracods belonging to the genera Vargula and Cypridinodes and isopods belonging to Cirolana were consistently captured in baited traps at Lizard Island (Keable 1995), indicating that a number of lagoon floor taxa contribute to the remineralization of detritus through scavenging. The fact that the distribution and abundance of the lagoon floor community mirror the seasonal distribution and availability of particulate nutrients, but not the in situ primary production, suggests that the primary trophic role of the lagoon hyperbenthic community is the remineralization of organic detritus. As large areas of Indo-Pacific coral reefs and atolls are either sandy lagoons or backreef slopes and given the extremely high density of relatively large individuals, the trophodynamic contribution of the lagoon hyperbenthos to coral reef ecosystems must be considerable.

Acknowledgements. We thank all the numerous field volunteers who assisted with this study, but specifically $\mathrm{T}$. Done who skippered 'M.S. Velella', and A. Hatcher, L. Quetin, R. Ross, M. Jones, and P. Hamner for their endurance. We thank S. Talbot for assistance in the identification of mysids, A. Myers for identification of amphipods, L. Kornicker for identification of ostracods, G. Poore for identification of isopods, and J. Sieg for identification of tanaidaceans. We also thank I. Bush, S. Davies, and M. Temby for their valuable assistance with reference material.

\section{LITERATURE CITED}

Alldredge AL, King JM (1977) Distribution, abundance and substrate preference of demersal reef zooplankton at Lizard Island Lagoon, Great Barrier Reef. Mar Biol 41: 317-333

Alldredge AL, King JM (1980) Effects of moonlight on the vertical migration patterns of demersal zooplankton. J Exp Mar Biol Ecol 44:133-156

Alongi DM (1986) Population structure and trophic composition of the free-living nematodes inhabiting carbonate sands of Davies Reef, Great Barrier Reef, Australia. Aust J Mar Freshw Res 37:609-619

Alongi DM (1988) Detritus in coral reef ecosystems: fluxes and fates. In: Choat JH, Barnes D, Borowitzka MA, Coll JC and 14 others (eds) Proc 6th Int Coral Reef Symp, Vol 2. Symposium Executive Committee, Townsville, p 29-36
Alongi DM (1998) Coastal ecosystem processes. CRC Press, Boca Raton, FL

Anderson MJ (2000) DISTLM: a FORTRAN computer program to calculate a distance-based multivariate analysis for a linear model. Department of Statistics, University of Auckland

Anderson MJ (2003) XMATRIX: a FORTRAN computer program for calculating design matrices for terms in ANOVA designs in a linear model. Department of Statistics, University of Auckland

Belbin L (1987) PATN: pattern analysis package. Reference manual, Part 1. CSIRO Division of Wildlife and Rangelands Research, Melbourne

Birkett L, Mclntyre AD (1971) Treatment and sorting of samples: In: Holme NA, Mclntyre AD (eds) Methods for the study of marine benthos. Blackwell, Oxford, p 156-168

Bray JR, Curtis JT (1957) An ordination of the upland forest communities of southern Wisconsin. Ecol Monogr 27: 325-349

Carleton JH, Hamner WM (1987) A diver operated device for the capture of mobile epibenthic organisms. Limnol Oceanogr 32:503-510

Carleton JH, Hamner WM (1989) Resident mysids: community structure, abundance and small-scale distributions in a coral reef lagoon. Mar Biol 102:461-472

Carleton JH, McKinnon AD (2007) Resident mysids: secondary production, consumption, and trophic role in a coral reef lagoon. Mar Ecol Prog Ser 336:89-98

Clarke KR (1993) Non-parametric multivariate analyses of change in community structure. Aust J Ecol 18:117-143

Emery AR (1968) Preliminary observations on coral reef plankton. Limnol Oceanogr 13:293-303

Field JG, Clarke KR, Warwick RM (1982) A practical strategy for analysing multispecies distribution patterns. Mar Ecol Prog Ser 8:37-52

Gerber R, Marshall N (1974) Reef pseudoplankton in lagoon trophic systems. In: Cameron AM, et al (eds) Proc 2nd Int Coral Reef Symp, Vol 2. Great Barrier Reef Committee, Brisbane, p 105-107

Hamner WM, Carleton JH (1979) Copepod swarms: attributes and role in coral reef ecosystems. Limnol Oceanogr 24:1-14

Hansen JA, Klumpp DW, Alongi DM, Dayton PK, Riddle MJ (1992) Detrital pathways in a coral reef lagoon. II. Detritus deposition, benthic microbial biomass and production. Mar Biol 113:363-372

Jacoby CA, Greenwood JG (1988) Spatial, temporal and behavioral patterns in emergence of zooplankton in the lagoon of Heron Reef, Great Barrier Reef, Australia. Mar Biol 97:309-328

Johnson MW (1949) Zooplankton as an index of water exchange between Bikini lagoon and the open sea. EOS Trans Am Geophys Union 30:238-244

Keable SJ (1995) Structure of the marine invertebrate scavenging guild of a tropical reef ecosystem: field studies at Lizard Island, Queensland, Australia. J Nat Hist 29: $27-45$

Mauchline J (1980) The biology of mysids. Adv Mar Biol 18: 1-369

McArdle BH, Anderson MJ (2001) Fitting multivariate models to community data: a comment on distance-based redundancy analysis. Ecology 82:290-297

McKinnon AD (1991) Community composition of reef associated copepods in the lagoon of Davies Reef, Great Barrier Reef, Australia. Bull Plankton Soc Jpn Spec Vol:467-478

McWilliams PS, Sale PF, Anderson DT (1981) Seasonal changes in resident zooplankton sampled by emergence 
traps in One Tree lagoon, Great Barrier Reef. J Exp Mar Biol Ecol 52:185-203

Mees J, Jones MB (1997) The hyperbenthos. Oceanogr Mar Biol Annu Rev 35:221-255

Motoda S (1940) Comparison of the condition of waters in bay, lagoon and open sea in Palao. Palao Trop Biol Station Stud 2:41-48

Pielou EC (1969) An introduction to mathematical ecology. John Wiley \& Sons, New York

Pielou EC (1975) Ecological diversity. Wiley \& Sons, New York

Renon JP (1977) Zooplankton du lagon de l'atoll de Takapoto (Polynesie Francaise). Ann Inst Oceanogr 53:217-236

Riddle MJ, Alongi DM, Dayton PK, Hansen JA, Klumpp DW (1990) Detrital pathways in a coral reef lagoon. I. Macrofaunal biomass and estimates of production. Mar Biol 104: 109-118

Roman MR, Furnas MJ, Mullin MM (1990) Zooplankton abundance and grazing at Davies Reef, Great Barrier Reef, Australia. Mar Biol 105:73-82

Sale PF, McWilliams PS, Anderson DT (1978) Faunal relation-

Editorial responsibility: Otto Kinne (Editor-in-Chief), Oldendorf/Luhe, Germany ships among the near-reef zooplankton at three locations on Heron Reef, Great Barrier Reef and seasonal changes in this fauna. Mar Biol 49:133-145

Sandland RL, Young PC (1979a) Probabilistic tests and stopping rules associated with hierarchical classification techniques. Aust J Ecol 4:399-406

Sandland RL, Young PC (1979b) Tables of probabilities associated with the fission of replicate samples in classification. (CSIRO Div Fish Oceanogr) Report No. 108. CSIRO Division of Fisheries Oceanography, Melbourne

Tranter DJ, George J (1972) Zooplankton abundance at Kavaratti and Kalpeni Atolls in the Laccadives. In: Mukandan C, Pillai CSG (eds) Proceedings of the symposium on corals and coral reefs. Marine Biological Association of India, Cochin, p 239-256

Wilkinson CR (1987) Microbial ecology on a coral reef. Search 18:31-33

Winer (1971) Statistical principles in experimental design, 2nd edn. McGraw-Hill, New York

Zar JH (1984) Biostatistical analysis, 2nd edn. Prentice-Hall, Upper Saddle River, NJ

Submitted: May 25, 2006; Accepted: September 28, 2006 Proofs received from author(s): March 29, 2007 